\title{
Teaching Reform of Building Material Experiment Course Based on the Improvement of Students' Comprehensive Quality
}

\author{
Wei Chen ${ }^{1,2}$, Huiyan Jia ${ }^{1, *}$, Jiansheng Shen ${ }^{1}$ and Jian Geng ${ }^{1}$ \\ ${ }^{1}$ Senior Engineer, School of Civil Engineering and Architecture, Ningbotech University, Ningbo 315100, China. \\ ${ }^{2}$ School of Civil Engineering, Tianjin University, 92 Weijin Road, Tianjin 300072, China \\ Email: chenw@nit.zju.edu.cn \\ *Corresponding author. Email: huiyanj@126.com
}

\begin{abstract}
In order to strengthen the effectiveness of building materials experimental teaching, this paper based on the teaching content, teaching methods, evaluation system of these three levels of experimental teaching reform, and then summed up a more practical experimental teaching mode. Based on the trend of less class hours and more course content of building materials experiment course, two experimental teaching contents, including design and experiment, are integrated to improve and perfect the old teaching methods, so as to stimulate students' learning enthusiasm, improve students' practical skills, operation skills, innovation skills and the innovation ability to solve similar problems in the future.
\end{abstract}

Keywords: Architecture material, Experimental teaching, Teaching reform.

\section{INTRODUCTION}

The course of building materials belongs to civil engineering and construction, which is a basic course. Civil engineering, architecture, engineering management, road and Bridge major set it as a professional course. This course aims to enable students to master more principles of building materials, teach students how to choose materials, standardize the use of materials, etc. The practicality of the course is very strong, and the experimental part is the core content of the course. Through the experiment, students can apply the theory to practice, master the use of building materials, and further familiar with the characteristics and application scope of building materials, so as to improve the practical skills, operation skills and innovation skills [1-3].

In China, the experimental curriculum model is more traditional, which has obvious limitations, mainly in the following aspects: first, the content and form of the experiment is not rich enough, lack of practicality and novelty, which seriously restricts the development of students' thinking, and it is easier to weaken students' operation ability and practical ability; second, the experimental steps are too rigid Students must operate in strict accordance with the requirements of teachers, which can easily weaken their practical interest; third, the integration between experiments is not very strong, which makes students only master part of the content of the course, and it is difficult to achieve the mastery of knowledge, which can easily lead to students' lack of experience in dealing with practical cases; fourth, the evaluation way of experiments is not standardized, which can easily weaken students' experimental ability Fifth, the experimental evaluation index is not scientific enough, lack of flexibility and pertinence, which can easily weaken the students' inquiry and innovation [4,5].

At present, the experimental teaching methods of building materials in some colleges and universities in China cannot meet the mainstream requirements of the innovative development of higher education in the new era. In order to strengthen the teaching effectiveness of this course in our school, this paper puts forward the teaching reform methods, hoping that this paper can be a reference for the teaching work of relevant teachers. 
Table 1. The first level ---basic experiment

\begin{tabular}{|c|c|c|c|c|c|}
\hline $\begin{array}{l}\text { Serial } \\
\text { numb } \\
\text { er }\end{array}$ & Experimental project & Experiment content & $\begin{array}{l}\text { Class } \\
\text { hours }\end{array}$ & $\begin{array}{l}\text { Experiment } \\
\text { type }\end{array}$ & remarks \\
\hline 1 & Cement experiment & $\begin{array}{c}\text { cement specific surface area experiment } \\
\text { demonstration, standard consistency } \\
\text { water demand test, volume stability test } \\
\text { cake }\end{array}$ & 4 & Confirmatory & Mandatory \\
\hline 2 & Concrete experiment & $\begin{array}{l}\text { Determination of apparent density, bulk } \\
\text { density and screening of sand, bulk } \\
\text { density and screening, workability of } \\
\text { concrete mixture and strength grade of } \\
\text { concrete. }\end{array}$ & 6 & $\begin{array}{l}\text { Comprehensiv } \\
\mathrm{e} \\
\text { Designability }\end{array}$ & Mandatory \\
\hline 3 & $\begin{array}{c}\text { Reinforcement } \\
\text { experiment }\end{array}$ & $\begin{array}{c}\text { The tensile, cold drawing and aging } \\
\text { strengthening experiments were carried } \\
\text { out. }\end{array}$ & 2 & Confirmatory & Mandatory \\
\hline 4 & $\begin{array}{l}\text { Experiment of asphalt } \\
\text { technical properties }\end{array}$ & $\begin{array}{l}\text { Penetration, ductility, softening point } \\
\text { and lightning test of asphalt. }\end{array}$ & 2 & Confirmatory & $\begin{array}{l}\text { Selected } \\
\text { works of road } \\
\text { and Bridge } \\
\text { Specialty }\end{array}$ \\
\hline 5 & Decorative materials & $\begin{array}{l}\text { The experiment of sound absorption } \\
\text { and heat preservation of decorative } \\
\text { materials. }\end{array}$ & 2 & Confirmatory & $\begin{array}{l}\text { Selected } \\
\text { works of } \\
\text { architecture } \\
\text { major }\end{array}$ \\
\hline 6 & Durability of concrete. & $\begin{array}{l}\text { Carbonation of concrete, corrosion of } \\
\text { steel bar in concrete, alkali aggregate } \\
\text { reaction, freeze-thaw damage of } \\
\text { concrete, chloride ion erosion. }\end{array}$ & 2 & Confirmatory & $\begin{array}{l}\text { Civil } \\
\text { engineering } \\
\text { and road and } \\
\text { Bridge }\end{array}$ \\
\hline 7 & $\begin{array}{l}\text { Masonry material and } \\
\text { steel member } \\
\text { experiment }\end{array}$ & $\begin{array}{l}\text { The physical properties of brick and } \\
\text { block and the slip coefficient of steel } \\
\text { members are tested. }\end{array}$ & 2 & Confirmatory & $\begin{array}{l}\text { Selection of } \\
\text { engineering } \\
\text { management } \\
\text { and civil } \\
\text { engineering }\end{array}$ \\
\hline
\end{tabular}

\section{TEACHING REFORM MEASURES}

\subsection{Optimization of Experimental Teaching Content}

The experimental course of building materials course is a practical course. The curriculum reform must adhere to the dominant position of students, so as to improve students' practical ability and innovation ability, and guide students to learn to apply what they have learned on the basis of mastering knowledge. In this paper, the experimental teaching knowledge is reformed, and the verification experimental course is integrated into the comprehensive practical course; in addition, according to the type of experimental project, the course is divided into two types, namely basic experimental type, innovative and open type, etc. The former is in line with the syllabus, focusing on verification courses and design courses, which are skills that students must master; the latter focuses on the integration of key and difficult points of knowledge, which can integrate engineering knowledge and pay attention to knowledge innovation. This course is an elective course, and some students with high learning enthusiasm can choose these courses.

\subsection{Reform of Experimental Teaching Methods and Means}

In order to strengthen the experimental teaching effect of building materials course, this paper sums up more scientific teaching methods from different angles, such as demonstration teaching, discussion and cooperation, task driven, centralized teaching and individual guidance, open teaching and so on. There are two types of experimental content, namely basic experimental type and innovative and open type. The former mainly focuses on the teaching of knowledge, adopts the combination of classroom teaching and video teaching, and uses the form of discussion cooperation and task driven for the design and comprehensive courses. The latter mainly adopts open teaching, centralized teaching and individual guidance. In addition, the former course must be carried out in class, which belongs to the practice in class. The latter can be combined with the third semester of civil engineering comprehensive training as part of the comprehensive training. In addition, it can be completed through the following ways, namely, innovation and entrepreneurship plan, challenge competition, social practice, scientific research projects, etc. the discussion and interaction is not limited to in class, but also can be 
Table 2. The second level----innovation and opening experiment

\begin{tabular}{|c|c|c|c|}
\hline $\begin{array}{l}\text { Serial } \\
\text { number }\end{array}$ & $\begin{array}{l}\text { Experimental } \\
\text { project }\end{array}$ & Experiment content & Purpose of the experiment \\
\hline 1 & $\begin{array}{l}\text { Experiment of } \\
\text { water reducing } \\
\text { agent }\end{array}$ & $\begin{array}{l}\text { Compatibility of the } \\
\text { superplasticizer } \text { and } \\
\text { cement based on } \\
\text { rheology. }\end{array}$ & $\begin{array}{l}\text { Basically master the influence of superplasticizer on the } \\
\text { fluidity of different cement, distinguish the compatibility of } \\
\text { cement and superplasticizer, learn to explore the influence of } \\
\text { superplasticizer on the fluidity of cement paste mixed with fly } \\
\text { ash and expansive agent, and urge students to further master } \\
\text { the effect and mechanism of superplasticizer. }\end{array}$ \\
\hline 2 & $\begin{array}{ll}\text { Experiment } & \text { on } \\
\text { performance } & \text { of } \\
\text { concrete } & \\
\text { admixture } & \end{array}$ & $\begin{array}{l}\text { The activity and } \\
\text { activity of the } \\
\text { admixture were excited. }\end{array}$ & $\begin{array}{l}\text { By using the active excitation test of admixtures and the } \\
\text { physical and mechanical properties test of admixtures, the } \\
\text { students can master the types of industrial solid wastes, as } \\
\text { well as the use mode and use value of wastes, so as to further } \\
\text { master the active mechanism of alkaline excitation and sulfate } \\
\text { excitation on pozzolanic industrial solid wastes. }\end{array}$ \\
\hline 3 & $\begin{array}{l}\text { Cement hydration } \\
\text { experiment }\end{array}$ & $\begin{array}{l}\text { The setting time, } \\
\text { hardening strength and } \\
\text { hydration heat of } \\
\text { cement are compared. }\end{array}$ & $\begin{array}{l}\text { Teach students how to predict the strength development and } \\
\text { hydration characteristics of cement, so that students can be } \\
\text { familiar with the physical and chemical reaction process of } \\
\text { cement hydration, and master another cement performance } \\
\text { measurement method. }\end{array}$ \\
\hline 4 & $\begin{array}{l}\text { Design of new } \\
\text { wall materials }\end{array}$ & $\begin{array}{l}\text { Foam concrete, phase } \\
\text { change energy storage } \\
\text { wall, insulation and } \\
\text { structural integrated } \\
\text { wall. }\end{array}$ & $\begin{array}{l}\text { Be familiar with the influence of new wall materials on } \\
\text { building performance, and understand the development ideas } \\
\text { and methods of new wall materials. }\end{array}$ \\
\hline 5 & $\begin{array}{l}\text { Design of high } \\
\text { performance } \\
\text { concrete }\end{array}$ & $\begin{array}{l}\text { The design of pump } \\
\text { concrete mix proportion } \\
\text { and self } \\
\text { comprete r r mix } \\
\text { proportion. }\end{array}$ & $\begin{array}{l}\text { Understand the design process and basic ideas of special } \\
\text { concrete. Deepen students' understanding of special concrete. }\end{array}$ \\
\hline 6 & $\begin{array}{l}\text { Design of new } \\
\text { road materials }\end{array}$ & $\begin{array}{l}\text { Design of permeable } \\
\text { asphalt mixture and } \\
\text { permeable concrete. }\end{array}$ & $\begin{array}{l}\text { Understand the role of new pavement materials in the } \\
\text { construction of sponge City, and be able to design permeable } \\
\text { asphalt mixture and permeable concrete. }\end{array}$ \\
\hline
\end{tabular}

realized through the Internet.

\subsection{Reform of Experimental Assessment Mechanism}

In the building materials experiment course, the innovative and open experiment course is integrated, but the evaluation mechanism for this kind of experiment can' $\mathrm{t}$ be limited to the experimental report and experimental results, but to improve the comprehensiveness and pertinence of the evaluation, evaluate the students' practical ability and operation ability from multiple levels, and integrate the students' specific performance in the experimental process, so as to develop a comprehensive evaluation system The specific operation is as follows:

(1) In order to improve the scientificity and fairness of the evaluation, the old evaluation mechanism should be reformed, and the combination of process evaluation and result evaluation should be carried out. For the first experimental course, the main way is the assessment of teachers and students. For the second experimental course, the main way is comprehensive evaluation. In addition, teacher-student assessment is the main way of evaluation. Students carry out self-evaluation and mutual evaluation on their own performance, and teachers work out the final evaluation results on the basis of the evaluation results. This evaluation method is obviously scientific and advanced. It can not only improve the teaching effect of the experimental course, but also enable the students to understand their shortcomings and provide reference for formulating targeted corrective measures, thus laying the foundation for later study. In addition, it helps to improve students' practical ability, operation ability and social adaptability; in addition, it helps teachers to improve their own teaching methods, points out the direction for the later teaching practice rectification, and provides a strong reference for the establishment of a perfect experimental evaluation system. The comprehensive evaluation takes the form of propaganda and small papers, which is to evaluate the degree of effort in the experimental process and the practicality and innovation of the results.

(2) In addition, the experimental report should be rectified to improve the scientificity and standardization of the report, and the combination of process evaluation and result evaluation should be adopted. Pay more attention to the performance of students in the experimental process, pay more attention to the cultivation of students' practical ability and operation ability, and improve their problem-solving ability, inquiry ability and innovation ability. Results diversity assessment pays more attention to the cultivation of students' skills, and the types of results become more 
abundant, such as final report, research paper, survey report, etc. In order to complete the experiment, students must do sufficient market research, collect information comprehensively, and make the experiment plan, so as to provide reliable guarantee for the practical operation. After the completion of the experiment, students should explore and summarize the data, and finally develop a more perfect experimental results. In this process, students should not only actively explore, but also actively think, but also learn to work together in groups. In short, the new evaluation system helps to comprehensively improve students' comprehensive ability, with obvious effectiveness and scientificity.

\subsection{Implementation Plan and Schedule}

The arrangement of the basic experiment content is based on the syllabus, integrating the verification type, design type curriculum and comprehensive experiment. Some subjects are required to master, and the other part is according to the characteristics of each major, students choose subjects according to their own needs. Innovative and open experiment focuses on the integration of key and difficult knowledge, which can integrate engineering knowledge and pay attention to knowledge innovation. This course is an elective course, and some students with high learning enthusiasm can choose this course. The basic experiment and innovation and opening experiment are shown in charts 1 and 2 .

For the basic experiment, the combination of students' self-evaluation and teachers' evaluation is adopted. The students carry out self-evaluation and mutual evaluation on their own performance. The teacher formulates the final evaluation results on the basis of the evaluation results. The final score is composed of $30 \%$ attendance at ordinary times $+20 \%$ self-evaluation and mutual evaluation $+50 \%$ experimental results. The performance evaluation increases the assessment of usual attitude.

For the innovation and open experiment, the teacher can set several research topics, and the students can choose one of them freely. The number of students in each group is five to seven, and the team members should write research papers with references. Each group selects a representative to make a PPT report and give a lecture in class. The report time is about 10 minutes. The evaluation method for the performance is as follows: the proportion of homework attendance and lecture is $30 \%$ respectively, and the proportion of small papers is $40 \%$. This method pays more attention to the evaluation of the learning process.

\section{EFFECTIVENESS OF TEACHING REFORM}

In order to strengthen the effectiveness of teaching reform, this paper selects two classes of students majoring in civil engineering to carry out a comparative study, based on these aspects, namely, the similarity of experimental reports, students' practical ability, teachers' satisfaction with students of follow-up courses, etc., and summarizes the more comprehensive research results.

The following conclusions are drawn: the improved experimental teaching method has obvious advantages, the similarity of students' experimental reports is significantly reduced, the number of excellent students is significantly increased, and the satisfaction of subsequent course teachers to students is also significantly improved. This shows that the improved experimental teaching method has significant scientificity and effectiveness, which helps to strengthen the teaching effectiveness and significantly improve students' practical ability and operation ability. This teaching method is worthy of promotion and helps to improve the teaching quality of civil engineering graduates.

\section{CONCLUSION}

In order to cultivate more and more high-quality talents, based on these aspects, the reform of building materials experiment course is carried out, including course content, teaching methods, evaluation mechanism, etc., and a more scientific reform plan is formulated. The experimental ability of students before and after the reform is compared and analyzed. The results show that this teaching reform is helpful to improve the teaching effectiveness of the experimental course and is more beneficial to the students To improve students' practical ability and operation ability.

Based on the current situation of building materials experiment teaching, this paper finds out the disadvantages, designs and explores the teaching methods, contents and assessment methods of building materials experiment course, combines the theoretical teaching, experiment, practice and other teaching links, and puts forward that active and innovative learning should be integrated into all teaching links of building materials experiment course, so as to improve the quality of students The initiative and innovation ability in theory learning and practice should be enhanced to cultivate students' ability of independent learning, experimental design, practical operation and result analysis, and to change the traditional problems of emphasizing theory over experiment in building materials experiment teaching, and the practice link is mainly imitative operation and lack of innovative thinking. The results show that through reasonable teaching reform, the teaching effectiveness of building materials experiment course can be significantly improved, and the comprehensive quality of students can be improved. 


\section{AUTHORS' CONTRIBUTIONS}

W.C. led the research by writing the manuscript and data collection; H.J. assisted the data analysis and wrote the manuscript; J.S. contributed to data analysis and validation of the outcomes; J.G. contributed to analysis and validation.

\section{ACKNOWLEDGMENTS}

The authors wish to acknowledge the financial support of the Ningbo Tech University (NITJG-201919), Zhejiang Provincial Laboratory Work Research Project(YB202132) and the cooperative education project of Zhejiang provincial (Reform and innovation of civil construction curriculum system based on "intelligent construction" under the background of new engineering).

\section{REFERENCES}

[1] Dimmock, C., Tan, C. Y., Nguyen, D., Tran, T. A., \& Dinh, T. T. (2021). Implementing education system reform: Local adaptation in school reform of teaching and learning. International Journal of Educational Development, 80,102302 . doi:10.1016/j.ijedudev.2020.102302.

[2] Hassan, N. F., Puteh, S., \& Buhari, R. (2015). Student Understanding Through the Application of Technology Enabled Active Learning in Practical Training. Procedia - Social and Behavioral Sciences, 204, 318-325. doi:10.1016/j.sbspro.2015.08.158.

[3] Liu, P.-h., \& He, S.-b. (2018). Analysis of teaching reform mode based on cognitive computing system - An example of dragon boat teaching. Cognitive Systems Research, 52,978-984. doi:10.1016/j.cogsys.2018.09.013.

[4] He, Y. (2020). On the Teaching Reform of Mathematics Course in Independent Colleges.1088,1073-1080. doi:10.1007/978-981-15-1468-5_125.

[5] Gao, B. (2011). Study on the engineering practice course education teaching reform. Procedia Engineering, $\quad 15, \quad 4224-4227$. doi:10.1016/j.proeng.2011.08.792. 